\title{
The MOOC Revolution - massive open online courses: the answer to problems facing education or an experiment that could destroy centuries of tradition?
}

\author{
Katharine Jewitt \\ The Open University and University of Glasgow
}

\begin{abstract}
A radical rethink is going on about what it means to go to an educational institution, asking profound questions about what the classroom of the future should look like and the way we should learn. Given the emerging nature of massive open online courses (MOOCs), this paper is a synthesis of critical reflections, commentaries and cautionary tales from a variety of perspectives, looking at the issues facing education and considering whether traditional teaching methods have outlived their usefulness.
\end{abstract}

In times when educational institutions are facing financial cuts and student debt is increasing, some argue that free university online courses will be the saviour of education, (Koller et al, 2013). Others argue that they could destroy centuries of tradition and threaten some of the world's greatest universities (Vardi, 2012).

Much research focuses on the design and categorisation of MOOCs (Clark, 2013, Downes, 2010 and Reich, 2013) and the role of the educator (Ferguson and Whitelock, 2014). This paper builds on the research by examining some of the phenomenal changes to technologyenhanced learning being brought about by new technologies and business. It summarises some of the key discourses about MOOCs, which continue to generate heated debates and divide opinions about their credibility, value and importance. I argue that any form of technology that drives engaging education, tailored precisely to the needs of individuals, and opens up education to those who cannot afford it, must be a viable alternative and challenge traditional academic institutions both to question what they offer and respond accordingly.

Key Words: Technology-Enhanced Learning, MOOCs, personalised learning

\section{Introduction}

The word 'revolution' gets bandied about an awful lot, but I do not use the term lightly. A revolution is a great shift in the world's society, where an old system is thrown out and a new one is embraced. In all of history, success is made in revolutionary times. The difference with this particular revolution is that it presents a chance for education to spread to a lot more people on a global scale. The tools, technology and opportunities that are being developed are designed to empower people; lots of people. It is shaking the foundation stones of the academic world.

Year by year, a new technology arrives: over the last ten years, we've seen mobile and smart devices, tablets, e-books, WIFI and Bluetooth, gaming technologies, wearable technology, augmented reality, 3D virtual worlds and social networking. Christensen (1997) coined the term 'disruptive technology', which he describes as something that fundamentally challenges the status quo and changes the way we've always done things. He categorised 
them as disruptive because they challenge existing systems and models. Christensen discusses how large companies will often dismiss the value of a disruptive technology because it is not something they know and therefore regard it as conflicting with their business goals, only to discover later that they have missed out on the market share.

Revolutions work by destroying what was perfect and enabling a new kind of perfect, but this transformation cannot be immediate. The process in between is what the human species has to get right.

Much research focuses on the design and categorisation of MOOCs (Clark, 2013, Downes, 2010 and Reich, 2013) and the role of the educator (Ferguson and Whitelock, 2014). This paper builds on the research by examining some of the phenomenal changes to technologyenhanced learning being brought about by new technologies and business. It summarises some of the key discourses about MOOCs, which continue to generate heated debates and divide opinions about their credibility, value and importance.

This paper provides a brief overview of how education has been industrialised and suggests that it has, in this form, consequently outlived its usefulness.

The second section discusses the flipped classroom and how technology-enhanced learning is helping marginalised communities, with examples from Silicon Valley, home to some of the world's biggest technology companies whose research and development is focused on how people learn best. The paper looks at some specific examples, including Rocketship Education (which is focused on individualised learning), The Khan Academy (providing free education to anyone, anywhere), the use of tablets in schools, gaming, and platforms to personalise educational content.

The third section focuses on the phenomenal changes in education being brought about by MOOCs.

Finally, the paper summarises the discussions and makes recommendations for moving forward.

Throughout this paper, I argue that any form of technology that drives engaging education, tailored precisely to the needs of individuals, and opens up education to those who cannot afford it, must be a viable alternative and challenge traditional academic institutions to question what they offer and respond accordingly. The nature of educational research, learning and teaching is always changing and evolving: we academics cannot ignore anything with the potential to create powerful learning experiences that make educational environments connected, collaborative and personalised, developing in students the digital literacy skills essential to their growth in an ever-changing digital world.

The next section provides a brief look back at educational systems from early civilisations, thereby setting in context how the rules that created traditional teaching methods $2000_{+}$ years ago have outlived their usefulness. 


\section{The End of a System}

It is important to look back at our educational history dispassionately and recognise how resistant the field of education is to change and how little it has evolved (Waller, 1961). The origins of traditional education date back to early civilisations in Egypt and Babylonia when, in about 3100BC, trade, government and formal religion all began to rise (Mulhern, 1959). The emergence of education lies, to a large extent, inside the military. In Ancient Greece, boys began at the age of seven, learning by memorising, and training in preparation for joining the state militia at the age of twenty. The system was designed to create identical soldiers and administrators, trained in the art of war. This drive for conformity continued in systems of slavery and was evident during the rise of agriculture in the late middle ages. Landowners discovered that they could increase their wealth by having other people do the work for them (Orme, 2001 and Tutek, 1991). When the industrial revolution took place, from 1760 through to the mid-nineteenth century, wealthy mill owners, such as Richard Arkwright, wanted people with identical skills and identical knowledge to work in their factories. Twentieth century manufacturing assembly line owners, such as Henry Ford with his mass production of automobiles, also desired everybody to buy the same thing and wanted consumer conformity, too.

Montessori education (Montessori, 2009) is an educational method developed in the early 1900 s to move away from the factory model of school teaching and emphasises learning through all five senses. It's hands-on, self-paced, collaborative, challenging and enjoyable. It encourages students to take ownership and be responsible for their own learning, enabling them to choose what they want to learn depending on their interest. Divergent and innovative thinking is nurtured without the need for testing, grading and homework. Classrooms have mixed age groups spanning four years. The older children of the classes become leaders and mentors and younger children can see how their learning will develop by seeing what older children are working on.

Heppell (2011) discusses how, in this new, connected, world, the concept of education conveying content is dying and learning is just beginning. The idea of working on your own, sitting at a desk to take an exam paper which both student and teacher hope holds no surprises, is passé. Examinations prepare students for certainty by specifying a set syllabus which covers the examination questions, but the real world is not like that. Heppell believes that knowing anything is an obsolete idea, as, every day, we live in a world full of surprises. Everybody can find out anything online when s/he needs to know it, so teachers do not need to give answers. Learners who find out things for themselves will retain the information better. Education is no longer limited to what teachers can tell a student or limited by a text book, as content is available to everyone. Students are connected outside educational establishments and can gain access to a lot of information, exchange ideas, talk about more things and become more confident.

This section provided a brief look on the past and the end of the industrialisation of education. The next section takes a look at the new world of online education and the future of technology driving an education revolution, focusing on some specific examples of how technology is being utilised in marginal communities. 


\section{The New World of Online Education}

For some people, the new world of technology-enhanced learning is a time of great uncertainty and loss. It means something new and unexpected; it results in change and new practices. Mind-sets and attitudes have consequently to be changed, in order to provide students with a unique, value-added learning experience.

The concept of disruptive education can be looked at from the emergence of learning environments. In the first virtual learning environments, tools were provided by the educational institutions and teachers chose which to use for their courses. Personal learning environments (PLEs), where learners create their own learning space, have now superseded them. There is a pick and mix of cloud-based tools and institutional tools. More recently, building on PLEs, has been the emergence of 'The Internet of Things' (IOT), the networked connection of people, process, data and things, which is the basis for the Internet of Learning Things (IoLT) (Edutech Associates, 2013). It allows for seamless learning across different devices and in a variety of contexts.

The flipped classroom flips education on its head from a traditional lecture-centric approach to a learner- and activity-focused one. Students watch videos and complete online activities prior to attending face-to-face discussion sessions. Teacher time is then focused on problem-solving and collaborative activity. Students have the benefit of watching lectures at home at their own pace and at a time to suit them and are able to collaborate with peers and teachers through online discussions. Instruction is delivered outside the classroom and homework activities are brought into classroom hours, where teachers dedicate their time to explaining difficult concepts and can provide instructional and personalised support in the classroom and encourage group collaboration to work on ideas. Class time is set for work that used to be set for homework, but now the teacher can help students with what they are finding most difficult or set new challenges for those students who are racing ahead.

Sal Khan spawned the debate on flipping the classroom. He is the man behind 'The Khan Academy', an online teaching service whose mission is to provide a free, open, world-class education to anyone, anywhere. It is backed by Bill Gates and Google who have donated more than two million dollars (Khan Academy, 2014). Khan was a Boston hedge-fund analyst who began tutoring his cousin remotely over the telephone, using a simple computer program called Yahoo Doodle. After his cousin passed with flying colours, Khan received many more requests from relations and friends and decided to publish his lessons with open access and post them on YouTube, a video-sharing website.

Today, it is arguably the world's largest school, with ten million people using the site every month and over half a million registered teachers using the academy in their classrooms. There are over 400,000,000 lessons translated into twenty-eight languages and around four million exercises are completed every day (Khan Academy, 2014). The website contains practice exercises, instructional videos, dashboard analytics and teacher tools, all of which which empower students to study at their own pace, whether inside or outside a classroom.

In a traditional classroom, it is very hard for teachers to know who is understanding the subject matter and who is not. The Khan Academy is supporting a classroom of the future, providing a personalised kind of education through videos. The videos are typically ten minutes long. When students struggle, they can pause and rewind and make a note of 
questions they want to ask their teacher later. Every time the student uses it, the system is improving its knowledge of what the student may or may not know. Based on this, the system recommends what the student should do, teaching the child what $\mathrm{s} /$ he needs to know and not a whole class. Each child is receiving an education tailored precisely to personal needs so that there are no gaps in her/his knowledge.

The teacher is told what skills students have mastered, the number of attempts and how long it took for the student to complete the activity. What is so powerful is that it tells the teacher the exact problem the student has encountered. The teacher can thus intervene and clear up quickly something that, in a traditional context, the student could have struggled with for years. The best teacher in the world cannot know as much as the Khan dashboard. It knows everything a child does, where s/he went wrong, what videos s/he watched. Students earn energy points and badges so they can update their avatars. The computer is driving the teaching and the teacher role is that of mentor.

Khan is not alone in driving the revolution and it is not just technology driving developments in education, either. Astonishing advances in brain science are allowing us to learn much more about how neurological connections are made, why we remember what we do and how we may enhance that process... and gaming technology taps into all of this. Neuroscientists have discovered how the brain can rewire and change itself in response to behavioural conditions (Marcus, 2009). Detailed human mapping is taking place with new imaging technology, which Former US President Barack Obama likened to the 'space race' (The White House, 2013).

Nolan Bushnall, founder of Atari and modern video games, has brought his knowledge to Brainrush, making education as addictive as video games. Anyone can log on to the website and study a range of subjects by playing games for free, which provide personalised practice to develop their fluency. Brainrush allows teachers to assign activities to students or to create their own and monitor progress in real time, assigning remedial or advanced work according to the needs of each student.

Children want to play video games and want to design them. With gaming technology, learning can be ten times faster and almost anything can be learned in a game (Rivero, 2013). In a two-year test, run on Spanish language vocabulary, involving over 2,000 teachers and 80,000 students, the test participants claim to have increased learning speeds between eight and ten times those of traditional learning methods (Rivero, 2013). Bushall says that, by repeatedly playing various games on a subject, you can ensure you retain $100 \%$ of what you learn for the rest of your life and never forget it. The brain science indicates that we should be able to do this. It is a breath-taking thought and there's a huge amount of research to support this (Marcus, 2009). The use of gaming technology moves away from behaviourist learning, where learners are passive and being lectured to, and instead engages them in action- and problem-based learning. Students study, manipulate the content and work with it. They apply the content rather than simply memorise it. In a study of 225 studies of meta-analysis, it was found that undergraduate students in classes with traditional stand-and-deliver lectures were 1.5 times more likely to fail than students in classes using active learning techniques (Freeman et al, 2014).

In many developing countries, text books are not available because they are too expensive or, even if available, are out-of-date. Funding for developing new educational materials is 
often not forthcoming and access to educational resources is limited. The impact of such resources like the Khan Academy, on all stages of an individual's education, could be significant in emerging economies where access to high-quality educational resources will help support and improve teaching and learning. Blended learning is being adopted by Rocketship Education, a network of public elementary charter schools in the USA, serving primarily low-income students in neighbourhoods where access to excellent schools is limited (Rocketship, 2014). Around a quarter of the school day is spent online and results have soared. Rocketship students are outperforming students in the virtual comparison group in mathematics between 67\% (grade 3) and 89\% (grade 5). In addition, results show that Rocketship schools are significantly reducing the high-versus-low income achievement gap in grades 2 and 3, up to 75\% (Michael and Susan Dell Foundation, 2014).

Text books of the future can be and are being delivered on connective devices, which means that the incredible amount of data produced by students is calculable and usable. This allows teachers to detect where each student needs help and to focus their instruction on students' gaps in knowledge.

Jose Ferreria is the founder and CEO of Knewton, a former executive at Kaplan Inc. who has developed a platform to provide personalised educational content. As students progress through a course, it calculates what each student knows and when and how that student learns best, and then presents material that is most suited to that student in the format from which the student learns best. The data can calculate, for example, that a student learns mathematics best in the morning in fifty-minute blocks and is most effective when learning science in twenty-minute bite-sized chunks as their click rate declines. The data can show when students should take a break and whether they prefer short questions for some subjects and more complicated, difficult questions for others. The platform revisits material if the students did not fully understand the first time. The system gets smarter the more it is used and is able to predict failure in advance and prevent it from happening by presenting material for students to study, knowing that a student struggled with those concepts in a previous session. Knewton can take students to content from the previous month or year and can recognise that this student is similar to another student and therefore choose the same study strategy.

This kind of personalised learning stops students from feeling alienated, bored or frustrated because they don't understand their homework. The system has already predicted what content is required, so that the student has everything s/he needs prior to completing the piece of work. This benefits advanced children, who can unlock their potential and work at a faster pace and study more stimulating material. Students who need to work at a slower pace can do so and still fulfil their potential. It allows every student to have a path to success.

It is unclear what the full impact of all the educational technology discussed in this section will have on the future landscape of education. These open resources raise the debate about TEL and the role of openness as a driver for innovation, equity and access. Since much of the running in this new world of online education is being made by people who stand to generate a great deal of money, perhaps this is the answer to the present funding crisis. Have traditional teaching methods outlived their usefulness? Whatever your opinion is of The Khan Academy or games like Brainrush, they make traditional educational institutions question what it is they do and compare the value of online learning to a face-to-face, 
campus-based experience. Examples such as The Khan Academy and Knewton provide teachers with an opportunity to review how they work with their students and to rethink their values and delivery of learning, which can only be a good thing. The next section takes a look at whether MOOCs are the answer to problems facing higher education.

\section{The MOOC Revolution}

MOOCs are courses that are open, participatory and provide lifelong networked learning. They provide a way to connect and collaborate and for participants to develop their digital skills and engage in the learning process. In a MOOC, participants choose what they want to do and how they want to participate. They are a means of working and talking together in a structured way because part of the course requires collaborative engagement with the material together with both other participants and other material found; students must make connections with ideas and their network. The content of a MOOC knits together to create a networked forest of resources. There's no right or single path to study, which promotes independence whilst working in your own space; networked connections are also created from engagement with others.

A MOOC has been defined as:

"an open-access online course (i.e., without specific participation restrictions) that allows for unlimited (massive) participation. Many MOOCs provide interactive elements to encourage interactions among students and between students and the teaching staff, although the latter is not a defining requirement." (Kaplan and Haenlein, 2016)

In these times, when educational institutions are facing financial cuts and student debt is increasing, some argue that free university online courses will be the saviour of education, (Koller et al, 2013). Others argue that they could destroy centuries of tradition and threaten some of the world's greatest universities (Vardi, 2012).

The role of openness as a drive for innovation, equity and access to learning has gained increasing interest in recent years, partly through the emergence of open educational resources (OER), a term first used at UNESCO's 2002 'Forum on the Impact of Open Courseware for Higher Education in Developing Countries' (Witherspoon, 2002), but, most recently, through MOOCs. The idea of the MOOC Revolution is driving a huge shift from an education system based on memorisation and knowledge recall to a world of engagement of the mind and of the development of skills for problem solving, thinking and retrieving and utilising information effectively.

Some see MOOCs as disruptive technology; for others, they constitute the greatest opportunity in history. MOOCs are challenging traditional academic institutions to radicalise the way they deliver education, thus taking a step towards global education. MOOCs allow anyone in the world to have access to education entirely from their home. However, how to invigilate tests does present significant challenge, as does knowing that people are who they say they are!

There are various types of MOOC (Cusack, 2014). The XMOOC has a core curriculum and a professor who runs recorded lectures that can be watched by students at any time. cMOOCs have course materials as a starting point and centre upon connectivity through student-tostudent interactions. DOOCs are distributed online collaborative courses, where the same 
materials are used at multiple institutions. Students are able to engage across institutions, but the exact administrations of the material can vary. BOOCs are big open online courses. but limited to a smaller number of participants, usually around fifty. SMOCs are synchronous massive online courses with lectures that are broadcast live, which requires all participants to be logged in at the same time. SPOCs are a version of a MOOC, that are small private online courses and mostly replicate the traditional classroom with teacher interactions and limited class sizes. They are often used locally with on-campus students (Kaplan and Haenlein, 2016). There are also Corporate MOOCs that are designed for employee training.

The first MOOC, created in 2008 by educators Stephen Downes and George Siemens, was called Connectivism and Connectivity Knowledge. It used many different platforms and resources for student engagement, including wiki pages, forums and Facebook groups. In 2011, Peter Norvig and Sebastien Thrun created 'Introduction to Artificial Intelligence'. 160,000 students from around the world signed up and over 20,000 completed the MOOC (McGill, 2014).

Following this, a number of companies emerged. In 2011, Coursera was set up by Andrew $\mathrm{Ng}$ and Daphne Koller (Mcgill, 2014) and in the following year, Udacity was created by Sebastien Thrun. Both are online technology platforms that host MOOCs in a wide variety of topics, by partnering with top-tier universities to offer free courses to anyone.

Coursera launched with an enrolment of $100,000+$ students on each of its first courses and now offers in the region of 1,000 courses provided by over 100 partners and has over eleven million students from at least 196 countries (Coursera 2015). In January 2014, it was reported (Cusack, 2014) that Coursera had over five million students, in 190 countries, studying its portfolio of 532 courses.

Udacity had 1.8 million students in 190 countries, studying its thirty-three courses. Udacity is radically rethinking what a university can do for its students. It has teamed up with companies from Silicon Valley to create 'universities by industry' and devise courses for their workplaces, matching students to jobs available. Courses are being built specifically to match job roles, and students, after studying the MOOC, can walk straight into jobs if they have performed appropriately.

\section{Pros and cons}

More children will leave school in the next thirty years than ever in history (OECD, 2012). Twenty-seven million teachers need to be hired by 2030 (UNESCO, 2014). Technologyenhanced learning is available to support a lifetime opportunity and we cannot fail on the delivery of building a successful future. The real advantage of MOOCs is their openness and capacity for widening participation and extending education to students who cannot afford education. Research by Coursera, however, shows that $85 \%$ of participants already have university degrees (Coursera, 2014). Laurillard, (2014) advises that we should always be asking how technology can help us in addressing ambitious educational goals. She goes on to explain how MOOCs could be used to train teachers in cities of developing countries and suggests that they could go on to train teachers in their local towns; these in turn could reach children who would otherwise receive no formal education.

A key advantage of MOOCs is scale and access. Providers such as Coursera are able to offer a high-quality product at a marginal cost. They provide students with a free education 
of the highest quality because, thanks to the numbers involved, the cost per student head is so low. As a result of free access to MOOCs and other resources like the Khan Academy, access to learning can be opened up beyond basic education and does not have to be limited by economic status. MOOCs have been heralded as opening university up to many people who would not otherwise get a university education and as having the ability to improve the quality of life of many people who cannot afford a formal education. MOOCs help minority students who are capable but unable to attend university to participate in courses. They also open up access for disabled or homebound students to study and interact with other students.

There are concerns about the effects these courses will have on the universities themselves and whether universities will be a thing of the past. There's concern that rich students will study at university and poor students through a computer (McGhee, 2012).

MOOCs facilitate interaction of students to ask questions and discuss better learning experiences through social and peer learning in a social community. Education in universities is back to teaching, engaging in dialogue and helping students to develop thinking and problem-solving skills and acquire a passion for discipline. These skills are much easier to harness in face-to-face settings and more difficult in an online context. On campus is where the development of skills will be; teachers there can push students forward and teach them to solve problems.

MOOCs are forcing universities to find more creative ways to improve the learner experience to attract and retain students. As universities evolve, MOOCS will help to improve what is on offer, educationally. The numbers currently registering on MOOCs are generating large sets of data providing a wealth of information on student registrations, the number of dropouts, the number of students attending particular lectures and subjects and the percentage of students who take the certified assessments. This data will help academic institutions to improve both their online and face-to-face offerings by providing a more personalised approach to teaching and feedback.

Data provided by MOOCs will help universities know how long students are studying for, which topics are most popular and where students are located, all of which will assist in the marketing of courses; certainly, understanding why students are dropping out of courses will serve to improve those courses and enable educators to decide which material is most successfully delivered via MOOCs. The data collected could well influence institutional student retention and advance the professional development of teachers, by serving to identify, and then illustrate via the MOOC videos, those delivery skills best suited to the teaching and learning environment.

To conclude, whatever you may think of free and open resources in education, such as MOOCs, Brainrush, the Khan Academy and Knewton, they are opening up learning opportunities for millions of students and offer a real solution to the pressing issue of those 100 million children who currently cannot afford formal education (UNESCO, 2014). MOOCs and other learning platforms offer these children a ladder to education and thus a way up from the poverty line.

The real value of these disruptive developments is that they are promoting social inclusion and forcing traditional schools, colleges and universities to question what they offer, by 
asking them what more they can do to provide for students. Whether the hype over these learning platforms comes to fruition is less important than their legacy in widening participation, opening access to education and producing a better quality and more personalised learning experience.

\section{Summary}

There is no doubt that phenomenal changes in education are occurring. Technology is starting to change radically the way we educate our children. Education is having to compete with leisure technology and the use of readily-available devices such as tablets and smartphones. Faster internet speeds, cheaper computing devices and greater scientific advances in the understanding of how our brain works and how we learn are opening up new opportunities for making effective use of technologies in education and expanding what is on offer online.

Various factors, such as MOOCs and the Khan Academy, are driving the success of free and open resources in education. Firstly, connectivity is opening up the world and MOOCs and other free resources demonstrate the scope of transmission. There is, more than ever before, increasing demand for educational institutions to provide for ever-greater numbers of students from a wider diversity of backgrounds. This is the first generation to live and breathe technology without trepidation and MOOCs are able to make knowledge accessible to significant numbers. As Tapscott (2009) discusses in his book 'Grown Up Digital', technology is 'like the air to them' and there is an imperative for academic institutions to equip our generation of learners with the digital literacy skills required to survive and prosper in an ever-changing and complex society in the twenty-first century (Jenkins 2009).

Secondly, content is everywhere and readily available. If anybody needs to know anything they can look it up on the internet. Education is no longer dependent on a teacher conveying knowledge from a textbook. There's a new emphasis on the development of skills rather than knowledge recall. Technology can get children passionate and excited about learning. Emotional interaction increases motivation and learning. Playing a game makes children interact more emotionally within an environment in which they are learning and these games can adapt and adjust to improve the level of learners.

But all this technology will not take us anywhere without the teachers. If lecturers are concerned that they can be replaced by a video then they should be worried, because, if what they do is exactly the same as they have always done, traditionally, rather than providing tailored tutoring and responses to students' questions and moving away from content-heavy delivery, then they should be replaced. Students, however, do want living, breathing teachers. The lecture videos in MOOCs may be instructive and helpful, but they do not replicate, for students, a real interactive presence in the room with them.

There is something tremendous about getting people together in a place where serendipitous interactions can happen, where you can have face-to-face mentoring between an instructor and students, where students can talk together and create together and learn to debate ideas. MOOCs do not replace this campus physical experience. The creation of MOOCs does not equalise the opportunity of students without access to education and that of students attending, say, The Massachusetts Institute of Technology in the USA or the 
University of Cambridge in the UK; MOOCS do, however, have the potential to enhance considerably the levels of performance of both.

Teachers are at the heart of education, orchestrating the game of learning and providing one-to-one support, riding with students the rollercoaster of discovery and often learning with them. Teachers in the twenty-second century will be asked to teach a generation of students they do not understand. The focus is no longer on passing on old knowledge, but equipping our future generations with mental agility and smartness to deal with (and none of us can predict it) what the future will hold. The task for teachers of the future will be how to use the immense power of technology and transform students into higher performers than previous generations. The flipped classroom goes beyond the borders of the classroom and extends our reach to children to help them learn and motivate them to learn. The data that the use of MOOCs and other platforms can provide, constitute for teachers, an unprecedented means of seeing where children are struggling and providing personalised learning.

Finally, today's students are born into a digital revolution with a 24/7 lifestyle immersed in technology. Educational institutions have to 'up' their game if they are to compete against the proliferation of technological competitors. Institutions need to address new competitive niches; teachers need to learn how to use technology effectively for learning.

The learning platforms discussed in this paper represent the modern age we live in. Maslen (2012) argues that MOOCs are challenging traditional institutional business models, but, whether or not they are here to stay, they are just the start of more evolutionary disruptive education to follow. What is important is that educators stop fearing what technology might do and take developments seriously, thus making more informed decisions about pedagogical design to deliver quality assurance and an enhanced, personalised learner experience.

\section{Reference list}

Christensen, C. (1997). The innovator's dilemma: When new technologies cause great firms to fail. Cambridge MA: Harvard University Press.

Clark, D. (2013) MOOCs: taxonomy of 8 types of MOOC. Available at: http://donaldclarkplanb.blogspot.co.uk/search?q=MOOCs:+taxonomy (Accessed: 24 September 2014).

Coursera. (2014) 'Coursera conference data.' Paper presented at the Coursera Partners' Conference. London, UK: University of London, 1-3.

Creelman, A. (2013) Make hay while the sun shines. Available at: http://acreelman.blogspot.co.uk/2013/05/make-hay-while-sun-shines.html (Accessed: 24 September 2014).

Cusack, A. (2014) MOOCs By the Numbers. Available at: http://ideas.ted.com/moocs-bythe-numbers-where-are-we-now (Accessed: 24 September 2014). 
Downes, S. (2010) Fairness and equity in education. Available at: http://www.huffingtonpost.com/stephen-downes/democratizing-education_b_794925.html (Accessed: 24 September 2014).

Edutech Associates (2013) Internet of Learning-Things. Available at: http://bit.ly/1g3wPGP (Accessed: 24 September 2014).

Ferguson, R.and Whitelock, D. (2014) 'Taking on different roles: how educators position themselves in MOOCs.' In: Rensing, C., de Freitas, S., Ley, T. and Murnoz-Merino, P.J. (eds.) Open Learning and Teaching in Educational Communities. Lecture Notes in Computer Science (8719). Cham: Springer International Publishing, 562-563.

Freeman, S., Eddy, S.L., McDonough, M., Smith, M.K., Okoroafor, N., Jordt, H. and Wenderoth, M.P. (2014) 'Active Learning increases student performance in science, engineering and mathematics.' Proceedings of the National Academy of Sciences, 111(23), 8410-8415.

Gutek, G. L. (1991) An historical introduction to American education, $2^{\text {nd }}$ edn. Long Grove: Waveland Press.

Heppell, S. (2011) Is this the death of education and the dawn of learning Melbourne: Paper presented at Creative Innovation, 16 November 2011.

Jenkins, H. (2009) Confronting the challenges of participatory culture: Media education for the 21st century. Available at:

https://mitpress.mit.edu/sites/default/files/titles/free download/9780262513623 Confronting the Challenges.pdf (Accessed: 24 September 2014).

Kaplan, A.M. and Haenlein, M. (2016) 'Higher education and the digital revolution: About MOOCs, SPOCs, social media, and the Cookie Monster.' Business Horizons, July-August 2016, 59(4), 441-450.

Khan Academy. (2014) Press Room. Available at: https://khanacademy.zendesk.com/hc/enus/articles/202483630-Press-room (Accessed: 24 September 2014).

Koller, D., Ng, A., Do, C. and Chen, Z. (2013) Retention and Intention in Massive Open Online Courses: In Depth. Available at: http://er.educause.edu/articles/2013/6/retention-andintention-in-massive-open-online-courses-in-depth (Accessed: 24 September 2014).

Laurillard, D. (2014) What is the problem for which MOOCs are the solution? Available at: https://altc.alt.ac.uk/blog/2014/06/what-is-the-problem-for-which-moocs-are-thesolution/\#gref (Accessed: 24 September 2014).

Marcus, G. (2009) Kluge: the Haphazard Construction of the Human Mind. London: Faber.

Maslen, G. (2012) MOOCs challenge higher education's business models. Available at: http://www.universityworldnews.com/article.php?story=20120831103842302 (Accessed: 24 September 2014).

McGhee, P. (2012) 'Why online courses can never totally replace the campus experience', Guardian, 19 November 2012 [Online], Available at 
https://www.theguardian.com/education/2012/nov/19/open-online-courses-higher-education (Accessed 24 November 2011).

McGill, (2014) A Brief History of MOOCs]. Available at: http://www.mcgill.ca/maut/currentissues/moocs/history (Accessed: 29 September 2014).

Michael and Susan Dell Foundation. (2014) Blended Learning Report. Available at: http://5a03f68e230384a218e0-

938ec019df699e606c950a5614b999bd.r33.cf2.rackcdn.com/MSDF-Blended-LearningReport-May-2014.pdf (Accessed: 24 September 2014).

Montessori, M. (2008) The Montessori Method. Radford: Wilder Publications.

Mulhern, J. (1959) A history of education: A social interpretation. $2^{\text {nd }}$ edn. New York: Ronald Press Co.

OECD. (2012) Education at a Glance 2012: Highlights, OECD Publishing. Available at: http://dx.doi.org/10.1787/eag_highlights-2012-en (Accessed: 29 September 2014).

Orme, N. (2001) Medieval Children. New Haven, CT: Yale University Press.

Reich, J. (2013) Is a MOOC a textbook or a course? Available at:

http://blogs.edweek.org/edweek/edtechresearcher/2013/05/is a mooc a textbook or a co urse.html (Accessed: 29 September 2014).

Rivero, V. (2013) Play It Again, Nolan. Available at:

https://edtechdigest.wordpress.com/2013/09/24/play-it-again-nolan (Accessed: 24

September 2014).

Rocketship (2014) Rocketship. Available at: http://www.rsed.org/index.cfm (Accessed: 24 September 2014).

Tapscott, D. (2009) Grown up digital: How the Net generation is changing your world. New York: McGraw-Hill.

The White House. (2013) Remarks by the President on the BRAIN Initiative and American Innovation. Available at: https://obamawhitehouse.archives.gov/the-press-

office/2013/04/02/remarks-president-brain-initiative-and-american-innovation (Accessed: 15 January 2017).

UNESCO (2014) How could adults by illiterate? Available at:

http://enikki.mitsubishi.or.jp/e/event/index6.html (Accessed: 24 September 2014).

UNESCO (2014) Wanted: Trained teachers to ensure every child's right to primary education. Available at: http://unesdoc.unesco.org/images/0022/002299/229913E.pdf (Accessed: 15 January 2017).

Vardi, M.Y. (2012) Will MOOCs Destroy Academia? Available at: http://cacm.acm.org/magazines/2012/11/156587-will-moocs-destroy-academia/fulltext (Accessed: 24 September 2014).

Waller, W. (1961) The sociology of teaching. New York: Russell \& Russell. 
Witherspoon, J. (2002) Open Courseware and Developing Countries: Building a Community. Report of the Forum on the Impact of Open Courseware for Higher Education in Developing Countries, convened in Paris by UNESCO 1-3 July 2002. Available at:

http://www.hewlett.org/wpcontent/uploads/2016/08/OpenCourseWareandDeveloping Countri es.pdf (Accessed: 29 September 2014). 